Journal of Economic, Business and Accounting (COSTING)

Volume 2 Nomor 1, Juli-Desember 2018

e-ISSN : 2597-5234

https://doi.org/10.31539/costing.v2i1.367

\title{
DETERMINAN NILAI PERUSAHAAN MANUFAKTUR: MODEL PENGUJIAN DENGAN CHOW-TEST DAN HAUSMAN-TEST
}

\author{
DETERMINANT OF MANUFACTURE COMPANIES' VALUE: \\ EXAMINATION MODEL BY USING CHOW-TEST DAN HAUSMAN-TEST \\ 1,2 Evelyn Wijaya, Yusnita Octafilia \\ ${ }^{1,2}$ Sekolah Tinggi Ilmu Ekonomi Pelita Indonesia \\ 1evelyn.wijaya@lecturer.pelitaindonesia.ac.id \\ 2yusnita.octafilia@lecturer.pelitaindonesia.ac.id
}

\begin{abstract}
The aim of company establishing is to increase company's value in order to give prosperity for its stakeholders. And there are many internal and external factors can influence the company's value. So, this study has aim to analyze determinant of manufacture companies's value by using ChowTest and Hausman-Test. This study has 109 manufacture companies with purposive sampling method and uses panel data regression as data analysis method. The examination of study model by using Chow-Test and Hausman-Test shows that the proper study model examination is Fixed Effect Model (FEM). The result of Fixed Effect Model shows that company size influences positifically and significantly on company's value. Then, institutional ownership and investment policy influence negatively and significantly on company's value. While, profitability, funding decision, devident policy, managerial ownership and cash holding do not influence significantly on company's value. As there is supervision from institution party on management performance, it is going to make management do financial decision that related with company's value movement carefully.
\end{abstract}

Keywords: Company's Internal Factors, Agency Theory and Company's value

\begin{abstract}
ABSTRAK
Perusahaan didirikan dengan tujuan untuk meningkatkan nilai perusahaan sehingga dapat memberikan kemakmuran bagi pemegang saham. Cukup banyak faktor-faktor yang memengaruhi nilai perusahaan baik yang bersumber dari internal maupun eksternal. Penelitian ini bertujuan untuk menganalisis determinan nilai perusahaan manufaktur dengan menggunakan pengujian chow-test dan hausman-test. Sampel yang digunakan sebanyak 109 perusahaan manufaktur dengan teknik purposive sampling. Metode analisis data yang digunakan adalah analisis regresi data panel. Pengujian model penelitian dengan menggunakan chow-test dan hausman-test menunjukkan bahwa model penelitian yang tepat digunakan adalah Fixed Effect Model (FEM). Hasil FEM memperlihatkan bahwa ukuran perusahaan berpengaruh positif dan signifikan terhadap nilai perusahaan, kepemilikan institusional dan kebijakan investasi berpengaruh negatif dan signifikan terhadap nilai perusahaan. Sedangkan profitabilitas, keputusan pendanaan, kebijakan dividen, kepemilikan manajerial dan cash holding tidak berpengaruh signifikan terhadap nilai perusahaan. Dengan adanya pengawasan yang dilakukan oleh pihak institusi terhadap kinerja manajemen maka manajemen akan lebih berhati-hati dalam mengambil keputusan keuangan yang dapat berimbas pada naik turunya nilai perusahaan.
\end{abstract}

Kata Kunci: Faktor Internal Perusahaan, Agency Theory dan Nilai Perusahaan 


\section{PENDAHULUAN}

Perusahaan dalam menjalankan kegiatannya mempunyai tujuan yaitu untuk mencapai keuntungan yang optimal serta memaksimalkan kekayaan investor/pemegang saham. Tujuan ini harus dapat diwujudkan sebagai upaya pelaksanaan aktivitas perusahaan yang berkelanjutan. Salah satu cara yang dapat dilakukan adalah dengan memaksimalkan nilai perusahaan. Nilai perusahaan mencerminkan harga yang bersedia dibayar oleh investor apabila perusahaan dijual (Sartono, 2008). Nilai suatu perusahaan tercermin melalui harga saham yang diperjualbelikan di pasar modal yang dapat dipengaruhi oleh kondisi yang terjadi di dalam perusahaan maupun di luar perusahaan. Dengan semakin banyaknya jumlah perusahaan yang beroperasional dan adanya kemajuan globalisasi maka menuntut perusahaan untuk melakukan inovasi terhadap produk/jasa untuk meningkatkan kinerja perusahaan

Sektor manufaktur menjadi salah satu sektor unggulan dalam mendorong percepatan pembangunan dan pemerataan ekonomi nasional serta menjadi penyumbang terbesar untuk pajak dan cukai. Berdasarkan data yang dirilis oleh United Nations Statistics Division pada tahun 2016, Indonesia menempati posisi keempat dunia dari 15 negara yang industri manufakturnya memberikan kontribusi terhadap Produk Domestik Bruto (PDB) lebih dari 10\%. Indonesia mampu menyumbangkan PDB hingga $22 \%$ setelah Korea Selatan (29\%), Tiongkok (27\%) dan Jerman (23\%). Sementara itu, berdasarkan laporan United Nations Industrial Development Organization (UNIDO), Indonesia menempati posisi kesembilan pada tahun
2016 dengan nilai tambah industri sebesar 225,67 miliar dolar AS dan pangsa pasar sebesar $1,83 \%$.

Akumulasi perolehan IHSG selama 10 tahun terakhir (2007-2016) memperlihatkan bahwa pada tahun 20102012 nilai IHSG mengalami peningkatan hingga mencapai nilai 4.316,69 namun mengalami penurunan pada tahun 2013 menjadi 4.274,18 dan kembali meningkat menjadi 5.226,95 pada tahun 2014. Penurunan IHSG terbesar terjadi pada tahun 2015 yakni sebesar 12,13\% menjadi 4.593,01. Penurunan ini disebabkan karena adanya kenaikan suku bunga Bank Sentral Amerika Serikat yang membuat investor asing mengalihkan sebagian dananya keluar dari instrumen portofolio Indonesia (nilai jual bersih dana investor asing di pasar modal sebesar 22,58 triliun). Pada tahun 2016, IHSG kembali mengalami peningkatan sebesar $15,32 \%$ yang dipengaruhi oleh sentimen eksternal (kemenangan Donald Trump dan keputusan menaikkan suku bunga acuan oleh bank sentral AS) serta sentimen internal (program tax amnesty).

Jika ditinjau dari rata-rata indeks harga saham sektor manufaktur, pada tahun 2010-2011 indeks saham manufaktur mengalami peningkatan sebesar $15,52 \%$ menjadi $9.167,22$ namun indeks saham mengalami penurunan sebesar $10,25 \%$ pada tahun 2012 . Indeks saham kembali mengalami peningkatan pada tahun 2013 dan tahun 2014 menjadi $8.754,58$ dan mengalami penurunan kembali pada tahun 2015 sampai dengan tahun 2016. Kondisi yang terjadi pada sektor manufaktur berbeda dengan kondisi yang terjadi pada IHSG. Sebagai salah satu sektor yang memberikan sumbangan terbesar untuk PDB 
seharusnya juga memberikan sumbangan yang cukup besar untuk IHSG.

Berbagai penelitian mengenai nilai perusahaan telah dilakukan dan berdasarkan hal tersebut dapat disimpulkan bahwa terdapat banyak faktor yang memengaruhi nilai perusahaan. (Sukirni, 2012) melakukan pengujian terhadap variabel kepemilikan manajerial, kepemilikan institusional, kebijakan dividen, dan kebijakan hutang terhadap nilai perusahaan. (Ramadan, 2016) melakukan pengujian terhadap variabel firm size, firm age, firm risk, sales revenue, operating cost, tax rate, net margin, capital expenditure, book value, earning per share, dividend per share dan payout ratio pada industri Jordanian. (Faridah, 2016) melakukan pengujian terhadap variabel keputusan investasi, keputusan pendanaan, kebijakan dividen dan tingkat suku bunga terhadap nilai perusahaan pada sektor manufaktur. (Nhan \& Ha, 2016) melakukan pengujian terhadap variabel cash holding, state ownership and firm value pada Ho Chi Minh City Stock Exchange dan Hanoi City Stock Exchange. (Ghalandari, 2013) melakukan pengujian terhadap variabel capital structure, dividend, ownership structure on firm value with growth opportunities as a moderating variable at Tehran Securities Exchange. (Putu et. al., 2014) melakukan pengujian terhadap variabel corporate social responsibility, good corporate governance and size on firm value with profitability as a intervening variable.

Tujuan penelitian ini adalah untuk menganalisis faktor-faktor internal (determinan) perusahaan yang dapat memengaruhi nilai perusahaan manufaktur.

\section{Agency Theory}

Teori ini menyatakan bahwa adanya suatu hubungan kerja yang tercipta antara pihak principal (investor) dengan pihak agent (manajer) yang dituangkan dalam suatu kontrak kerja sama. Hubungan antara principal dan agent dapat mengarah pada kondisi ketidakseimbangan informasi yang dikarenakan agent memiliki informasi yang lebih banyak mengenai kondisi internal perusahaan dibandingkan dengan principal. Selain itu, masing-masing pihak memiliki kepentingan yang berbeda terhadap perusahaan dimana principal menghendaki pertumbuhan keuntungan dan kesejahteraan akibat dari investasi yang dilakukan ke perusahaan sedangkan agent menghendaki kesejahteraan pribadi.

Agent memiliki kewajiban untuk memberikan sinyal mengenai kondisi perusahaan kepada principal sebagai perwujudan dari tanggung jawab atas pengelolaan perusahaan. Namun kondisi yang terjadi adalah informasi yang disampaikan tidak sesuai dengan kondisi real yang terjadi pada perusahaan. Hal inilah yang menjadi awal pemicu munculnya konflik keagenan yang pada akhirnya akan dikenal dengan asimetri informasi. Konflik yang terjadi antara principal dan agent dapat diminimumkan melalui suatu mekanisme pengawasan yang dapat menyelaraskan kepentingan antara kedua pihak. Pengawasan ini akan memunculkan biaya tambahan (biaya keagenan) yang dikeluarkan oleh perusahaan sebagai upaya untuk mengatasi konflik yang terjadi.

\section{Hubungan Antara Kepemilikan Manajerial dan Nilai Perusahaan}

(Rizqia, Aisjah, \& Sumiati, 2013)

melakukan penelitian mengenai nilai perusahaan dan menemukan bahwa 
kepemilikan manajerial berpengaruh positif terhadap nilai perusahaan. Dengan adanya pembagian besaran proporsi kepemilikan saham kepada pihak manajemen maka manajemen akan merasa menjadi bagian dari perusahaan sehingga setiap keputusan yang diambil akan mempertimbangkan kepentingan perusahaan dan pemegang saham. Kondisi ini akan menyebabkan peningkatan pada nilai perusahaan. Penelitian ini berbeda dengan penelitian yang dilakukan oleh (Wijaya, 2016), (Sofyaningsih \& Hardiningsih, 2011), (Sukirni, 2012) dan (Zahedi, Talebi, \& Aval, 2015).

H1 : kepemilikan manajerial berpengaruh positif terhadap nilai perusahaan manufaktur

\section{Hubungan Antara Kepemilikan Institusional dan Nilai Perusahaan}

Penelitian yang dilakukan oleh (Sukirni, 2012) menyatakan bahwa kepemilikan institusional berpengaruh positif signifikan terhadap nilai perusahaan. Semakin baik dan semakin intensnya pengawasan yang dilakukan oleh pihak institusi terhadap kinerja manajemen perusahaan, maka manajemen akan lebih berhati-hati dalam setiap pengambilan keputusan sehingga akan meningkatkan nilai perusahaan. Penelitian ini berbeda dengan penelitian yang dilakukan oleh (Wijaya, 2016), (Sofyaningsih \& Hardiningsih, 2011), dan (Zahedi, Talebi, \& Aval, 2015).

$\mathrm{H} 2$ : kepemilikan institusional berpengaruh positif terhadap nilai perusahaan manufaktur

\section{Hubungan Ukuran Perusahaan dan Nilai Perusahaan}

Ernawati, (2015) melakukan penelitian pada industri barang konsumsi dan menemukan bahwa ukuran perusahaan berpengaruh positif signifikan terhadap nilai perusahaan. Semakin besar perusahaan maka akan menarik minat investor untuk berinvestasi ke perusahaan. Hal ini dikarenakan perusahaan besar cenderung memiliki aliran keuangan yang stabil dibandingkan dengan perusahaan kecil. Investor tertarik untuk memiliki saham perusahaan sehingga menyebabkan harga saham dipasar modal akan menjadi tinggi yang pada akhirnya akan meningkatkan nilai perusahaan. Penelitian ini tidak sejalan dengan penelitian (Sutrisno, 2016), (Meidiawati, 2016), (Indriyani, 2017), (Gultom, Agustina, \& Wijaya, 2013), dan (Rahayu \& Asandimitra, 2014)

H3 : ukuran perusahaan berpengaruh positif terhadap nilai perusahaan manufaktur

Hubungan Antara Kebijakan Dividen dan Nilai Perusahaan

Penelitian yang dilakukan oleh (Rizqia, Aisjah, \& Sumiati, 2013) menemukan bahwa kebijakan dividen berpengaruh positif signifikan terhadap nilai perusahaan. Dividen menggambarkan besarnya tingkat keuntungan yang diperoleh investor dalam periode tertentu. Besar kecilnya dividen yang diterima investor dapat dijadikan penilaian terhadap kondisi perusahaan. Apabila semakin besar proporsi dividen yang diterima oleh investor maka menjadi penanda kondisi perusahaan yang sehat sehingga akan menarik investor lain untuk berinvestasi ke perusahaan. Kondisi ini akan menyebabkan harga saham perusahaan mengalami peningkatan yang akan berpengaruh terhadap peningkatan nilai perusahaan. Penelitian ini berbeda dengan penelitian yang dilakukan oleh (Faridah, 
2016), (Ramadan, 2016), (Wijaya, 2016), (Rizqia, Aisjah, \& Sumiati, 2013) dan (Sukirni, 2012).

H4 : kebijakan dividen berpengaruh positif terhadap nilai perusahaan manufaktur

Hubungan Antara Keputusan Pendanaan dan Nilai Perusahaan

Penelitian yang dilakukan oleh (Wijaya, 2016) menemukan bahwa keputusan pendanaan berpengaruh negatif signifikan terhadap nilai perusahaan. Peningkatan hutang sering dipandang sebagai sinyal negatif bagi investor karena menandakan bahwa perusahaan sedang mengalami kesulitan dalam hal pendanaan. Penggunaan hutang yang telalu besar dapat menimbulkan biaya kesulitan keuangan akibat adanya pembayaran bunga dan pokok pinjaman yang jatuh tempo. Hal ini menyebabkan penurunan pada nilai perusahaan. Penelitian ini sejalan dengan penelitian yang dilakukan oleh (Sukirni, 2012) dan (Faridah, 2016) namun berbeda dengan penelitian yang dilakukan oleh (Sofyaningsih \& Hardiningsih, 2011), (Rizqia, Aisjah, \& Sumiati, 2013), (Rahayu \& Asandimitra, 2014), (Gultom, Agustina, \& Wijaya, 2013), (Welley \& Untu, 2015), (Sutrisno, 2016), (Dhani \& Utama, 2017), dan (Asif \& Aziz, 2016). H5 : keputusan pendanaan berpengaruh negatif terhadap nilai perusahaan manufaktur

\section{Hubungan Antara Profitabilitas dan Nilai Perusahaan}

Penelitian yang dilakukan oleh (Sudiyatno, Puspitasari, \& Kartika, 2012) pada perusahaan manufaktur menemukan bahwa kinerja perusahaan (rasio profitabilitas) berpengaruh positif signifikan terhadap nilai perusahaan. Pertumbuhan jumlah keuntungan yang dicapai oleh perusahaan akan menyebabkan peningkatan terhadap harga saham perusahaan yang menjadi sinyal positif bagi investor dan calon investor akan prospek perusahaan ke depannya. Kondisi ini akan menambah daya tarik bagi calon investor untuk menginvestasikan dana ke perusahaan sehingga terjadi peningkatan jumlah permintaan saham yang pada akhirnya akan mengarah pada peningkatan nilai perusahaan. Hasil penelitian ini sejalan dengan penelitian yang dilakukan oleh (Dhani \& Utama, 2017), (Ernawati, 2015), (Welley \& Untu, 2015), (Meidiawati, 2016), (Sucuahi \& Cambarihan, 2016), (Rizqia, Aisjah, \& Sumiati, 2013). Namun berbeda dengan penelitian yang dilakukan oleh (Wijaya, 2016), (Rahayu \& Asandimitra, 2014), dan (Sutrisno, 2016)

H6 : kebijakan profitabilitas berpengaruh positif terhadap nilai perusahaan manufaktur

\section{Hubungan Antara Cash Holding dan Nilai Perusahaan}

Penelitian yang dilakukan oleh (Zahedi, Talebi, \& Aval, 2015) menemukan bahwa cash holding berpengaruh negatif signifikan terhadap nilai perusahaan. Apabila perusahaan memiliki cash holding yang tinggi maka akan muncul kekhawatiran dari investor bahwa manajemen perusahaan mempunyai kekuasaan yang lebih besar untuk menghamburkan sumber daya perusahaan dan menghabiskannya untuk investasi yang tidak menguntungkan. Penelitian ini sejalan dengan penelitian (Isshaq, 2009) namun berbeda dengan penelitian yang dilakukan oleh (Rahayu \& Asandimitra, 2014).

H7 : cash holding berpengaruh negatif terhadap nilai perusahaan manufaktur 


\section{Hubungan Antara Keputusan Investasi dan Nilai Perusahaan}

Penelitian yang dilakukan oleh (Rizqia, Aisjah, \& Sumiati, 2013) menemukan bahwa keputusan investasi berpengaruh positif terhadap nilai perusahaan. Semakin tinggi nilai keputusan investasi maka akan memberikan peningkatan pada nilai perusahaan. Perusahaan mempunyai kesempatan yang lebih besar untuk melakukan pengelolaan usahanya sehingga hal ini mampu menjadi daya tarik tersendiri bagi investor. Hasil ini berbeda dengan penelitian yang dilakukan oleh (Faridah, 2016).

H8 : keputusan investasi berpengaruh positif terhadap nilai perusahaan manufaktur

\section{Kerangka Model Penelitian}

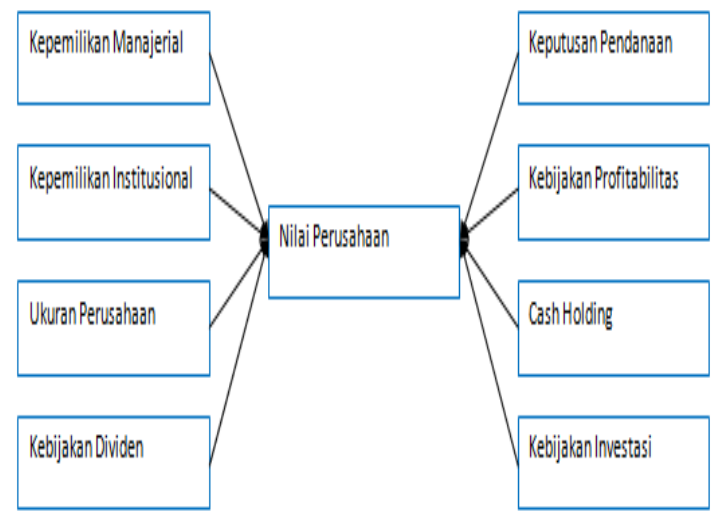

Sumber: Hasil Olahan,2018

\section{Gambar 1. Kerangka penelitian METODE PENELITIAN Populasi \& Sampel Penelitian}

Populasi yang digunakan dalam penelitian ini adalah industri manufaktur yang terdaftar di BEI periode 2010 2016. Industri manufaktur merupakan perusahaan yang memiliki jumlah yang paling banyak di BEI sehingga datanya bersifat representatif terhadap kondisi yang terjadi di BEI secara global.

Teknik pengambilan sampel yang digunakan adalah metode pemilihan non probability sampling dengan teknik purposive sampling. Kriteria yang digunakan dalam pemilihan sampel adalah perusahaan manufaktur yang sudah terdaftar di BEI sebelum tahun 2010, perusahaan yang didelisting selama periode penelitian dan perusahaan yang memiliki laporan keuangan yang lengkap. Berdasarkan kriteria pemilihan sampel yang telah diuraikan maka dapat diperoleh jumlah sampel penelitian sebanyak 109 perusahaan.

\section{Operasional Variabel}

Tabel 1. Operasional Variabel Penelitian

\begin{tabular}{|c|c|c|c|}
\hline & Turabal & Defaid & Iatlatut \\
\hline 1. & 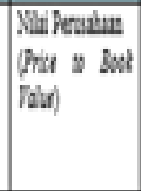 & 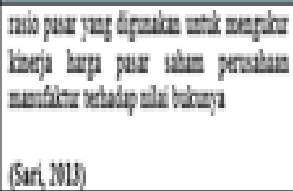 & 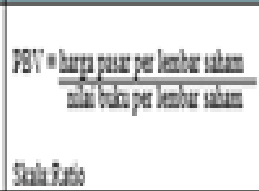 \\
\hline & laturestat & & \\
\hline 2 & 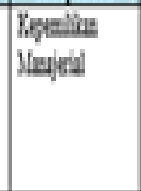 & 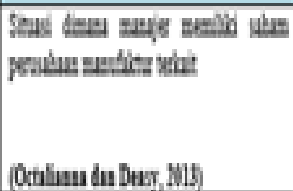 & 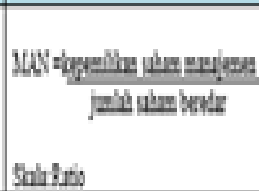 \\
\hline 1. & 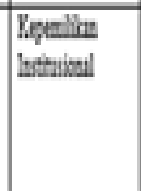 & 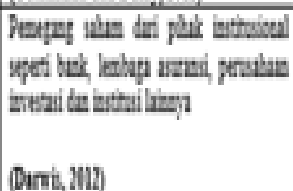 & 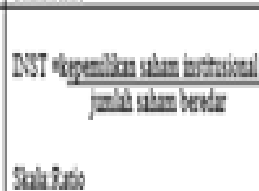 \\
\hline 4 & 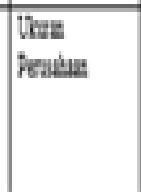 & 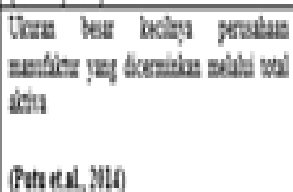 & 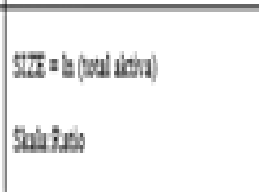 \\
\hline 3 & 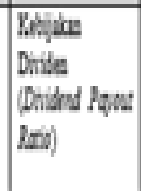 & 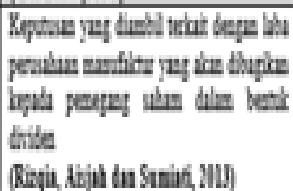 & 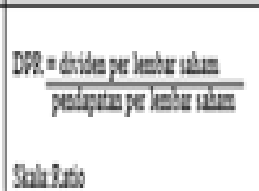 \\
\hline
\end{tabular}




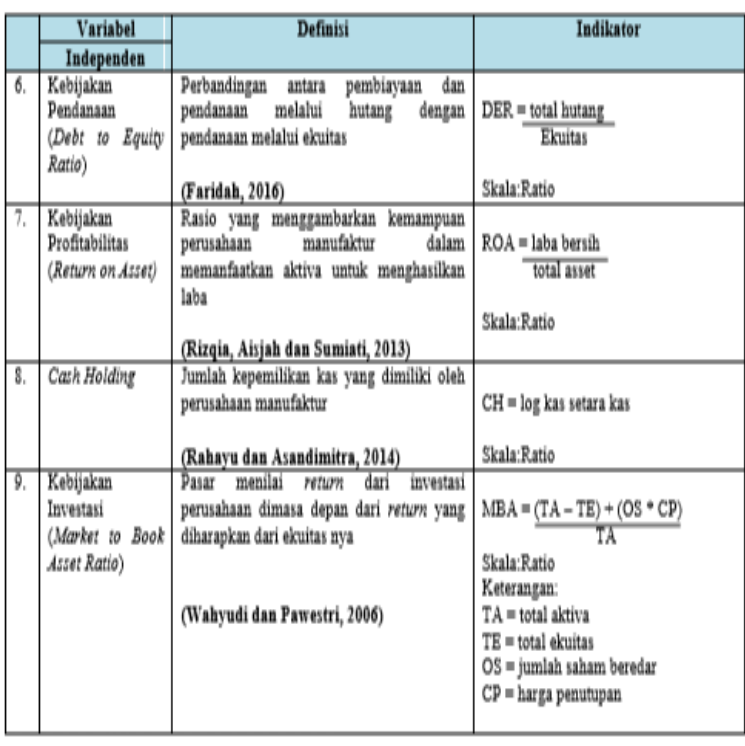

Sumber : Hasil Olahan, 2018

\section{Teknik Analisa Data}

Teknik analisa data yang digunakan adalah analisa regresi data panel dengan bantuan Eviews. Sebelum merancang persamaan regresi data panel maka akan dilakukan pengujian chow-test dan hausman-test untuk menguji model penelitian yang tepat. Adapun model regresi yang dihasilkan adalah :

$\mathbf{P B V}=\mathbf{B}_{0}+\mathbf{B}_{1} \mathbf{X}_{1}+\mathbf{B}_{2} \mathbf{X}_{2}+\mathbf{B}_{3} \mathbf{X}_{3}+\mathbf{B}_{4} \mathbf{X}_{4}$ $+B_{5} X_{5}+B_{6} X_{6}+B_{7} X_{7}+B_{8} X_{8}$

\section{HASIL DAN PEMBAHASAN \\ Chow-Test}

Uji Chow-Test digunakan untuk menentukan model Common Effect atau model Fixed Effect yang tepat digunakan dalam mengestimasi regresi data panel.

Tabel 2. Hasil Chow-Test

\begin{tabular}{ccc}
\hline Effect Tests & Statistics & Prob. \\
\hline Cross Section F & 3.1034 & 0.0000 \\
\hline $\begin{array}{c}\text { Cross Section Chi } \\
\text { Square }\end{array}$ & 318.8942 & 0.0000 \\
Sumber: & & \\
\hline
\end{tabular}

Sumber : Hasil Eviews 2018

Berdasarkan Tabel 2 terlihat bahwa nilai probabilitas yang dihasilkan lebih kecil dari 0,05. Hal ini menjelaskan bahwa model penelitian yang tepat adalah Fixed Effect Model (FEM).

\section{Uji Hausman-Test}

Salah satu teknik yang digunakan untuk pemilihan model terbaik adalah uji Hausman-Test yang dilakukan dengan cara membandingkan Fixed Effect Model dan Random Effect Model.

Tabel 3. Hasil Hausman-Test

\begin{tabular}{lcc}
\hline \multicolumn{1}{c}{ Effect Tests } & $\begin{array}{c}\text { Chi Square } \\
\text { Statistics }\end{array}$ & Prob. \\
\hline $\begin{array}{l}\text { Cross Section } \\
\text { Random }\end{array}$ & 97.7415 & 0.0000 \\
\hline
\end{tabular}

Sumber : Hasil Eviews 2018

Berdasarkan Tabel 3 terlihat bahwa nilai probabilitas yang dihasilkan dari uji Hausman-Test lebih kecil dari nilai alpha $(0,05)$ sehingga dapat dikatakan bahwa model yang tepat dalam penelitian ini adalah Fixed Effect Model (FEM).

Berdasarkan uji pendahuluan yang telah dilakukan (Uji Chow-Test dan Uji Hausman-Test) maka dapat ditarik kesimpulan bahwa penelitian ini akan menggunakan Fixed Effect Model (FEM) untuk mengestimasi model regresi data panel.

\section{Analisa Regresi Data Panel}

Analisa regresi data panel dilakukan untuk menguji hipotesis pengaruh variabel independen (X) terhadap variabel dependen (Y). Persamaaan model regresi yang terbentuk dalam penelitian ini adalah :

PBV = - 29.1405 MAN - 37.5680 INST + 12.1001 SIZE + 0.2163 DPR - 1.9336 DER + 2.0402 ROA - 0.3822 CH -0.1320 MBA

Koefisien Determinasi $\left(R^{2}\right)$

Nilai $\mathrm{R}^{2}$ menunjukkan seberapa kuat hubungan antara variabel independen dan variabel dependen. Nilai 
koefisien determinasi berkisar dari 0 dan 1. Semakin mendekati 1 , artinya model yang digunakan semakin bagus karena kesalahan yang tidak dapat dikendalikan semakin kecil.

Nilai Adjusted R-Square yang dihasilkan oleh FEM sebesar 0.4383 atau $43.83 \%$. Hal ini berarti bahwa sebesar $43.83 \%$ nilai perusahaan dipengaruhi oleh kepemilikan manajerial, kepemilikan institusional, ukuran perusahaan, kebijakan dividen, keputusan pendanaan, kebijakan profitabilitas, cash holding dan keputusan investasi sedangkan sisanya sebesar $56.17 \%$ dipengaruhi oleh variabel lainnya diluar penelitian seperti pertumbuhan perusahaan, likuiditas, resiko bisnis dan lain sebagainya.

\section{Uji Hipotesis (Uji t)}

Pengujian ini dilakukan untuk mengetahui pengaruh antara variabel dependen dan variabel independen secara parsial. Pengujian dilakukan dengan membandingkan nilai $\mathrm{t}$ hitung dan nilai $\mathrm{t}$ tabel atau melihat $p$-value masing-masing sehingga dapat ditentukan apakah hipotesis yang telah dibuat terpenuhi atau tidak.

\section{Tabel 4. Hasil Uji Hipotesis}

\begin{tabular}{ccc}
\hline Variabel & t-Statistics & Prob. \\
\hline MAN? & -1.8821 & $0.0603 * * *$ \\
\hline IO? & -3.9212 & $0.0001 * *$ \\
\hline CS? & 8.6205 & $0.0000 * *$ \\
\hline DPR? & 0.1984 & 0.8428 \\
\hline DAR? & -0.5824 & 0.5605 \\
\hline ROA? & 0.8830 & 0.3775 \\
\hline CH? & -0.0565 & 0.9550 \\
\hline MBVE? & -17.0134 & $0.0000 * *$ \\
\hline $\begin{array}{l}\text { Sumber : Hasil Eviews } \\
\text { 10\% da18 }(* * * \text { sig }\end{array} *$ sig 5\%) & \\
$\begin{array}{l}\text { Pengaruh } \\
\text { terhadap }\end{array}$ & Kepemilikan & Manajerial \\
Manufaktur & & Perusahaan
\end{tabular}

Hasil penelitian menemukan bahwa kepemilikan manajerial berpengaruh negatif dan signifikan terhadap nilai perusahaan. Hal ini sejalan dengan penelitian yang dilakukan oleh (Sukirni, 2012). Persentase kepemilikan manajemen terhadap saham perusahaan manufaktur pada sebagian perusahaan masih dikatakan rendah yaitu berada di bawah $1 \%$ sehingga hal ini mengakibatkan manajemen tidak merasa menjadi bagian dari perusahaan. Rendahnya persentase kepemilikan manajerial ini dapat menyebabkan munculnya tindakan yang lebih mementingkan kepentingan pribadi dibandingkan dengan kepentingan pemegang saham. Hal ini dapat berdampak negatif pada reaksi pasar saham yang pada akhirnya dapat menurunkan nilai perusahaan. Selain berdampak negatif terhadap pasar saham, rendahnya kepemilikan manajerial juga dapat menjadi penyebab munculnya agency problem.

Hasil penelitian ini berbeda dengan penelitian yang dilakukan oleh (Rizqia, Aisjah, \& Sumiati, 2013), (Wijaya, 2016), (Sofyaningsih \& Hardiningsih, 2011) dan (Zahedi, Talebi, \& Aval, 2015).

\section{Pengaruh Kepemilikan Institusional terhadap Nilai Perusahaan Manufaktur \\ Hasil penelitian menemukan} bahwa kepemilikan institusional berpengaruh negatif dan signifikan terhadap nilai perusahaan. Hal ini sejalan dengan penelitian yang dilakukan oleh (Wijaya \& Purnawati, 2014). Kondisi yang terjadi pada perusahaan manufaktur adalah bahwa sebagian besar kepemilikan saham perusahaan dikuasai oleh pihak institusi/perbankan asing sehingga 
mendorong pengawasan yang optimal. Apabila institusi tidak puas dengan hasil yang dicapai oleh manajemen maka pihak institusi mempunyai hak untuk menjual sahamnya ke pasar modal. Hal ini secara tidak langsung dapat berakibat pada penurunan nilai perusahaan.

Hasil penelitian ini berbeda dengan penelitian yang dilakukan oleh (Sukirni, 2012), (Wijaya, 2016), (Sofyaningsih \& Hardiningsih, 2011), dan (Zahedi, Talebi, \& Aval, 2015).

\section{Pengaruh Ukuran Perusahaan terhadap Nilai Perusahaan Manufaktur \\ Hasil penelitian menemukan} bahwa ukuran perusahaan berpengaruh positif dan signifikan terhadap nilai perusahaan. Hasil penelitian ini sejalan dengan penelitian yang dilakukan oleh (Ernawati, 2015). Sebagian besar perusahaan manufaktur merupakan perusahaan yang sudah beroperasional selama lebih dari 10 tahun. Semakin besar ukuran suatu perusahaan menandakan bahwa perusahaan telah memiliki aliran kas yang stabil guna membiayai aktivitas investasi. Perusahaan akan menggunakan pendanaan internal terlebih dahulu untuk membiayai aktivitasnya. Hal ini dapat menjadi daya tarik bagi investor sehingga akan menyebabkan harga saham perusahaan di pasar modal menjadi tinggi yang pada akhirnya akan meningkatkan nilai perusahaan.

Hasil penelitian ini tidak sejalan dengan penelitian yang dilakukan oleh (Sutrisno, 2016), (Meidiawati, 2016), (Indriyani, 2017), (Gultom, Agustina, \& Wijaya, 2013), dan (Rahayu \& Asandimitra, 2014).

\section{Pengaruh Kebijakan Dividen terhadap Nilai Perusahaan Manufaktur}

Hasil penelitian menemukan bahwa kebijakan dividen tidak berpengaruh signifikan terhadap nilai perusahaan. Hasil ini sejalan dengan penelitian yang dilakukan oleh (Wijaya, 2016) dan (Sukirni, 2012). Kebijakan dividen menggambarkan besarnya keuntungan yang akan diperoleh pemegang saham dari hasil investasinya. Dalam penelitian ini besar kecilnya dividen yang diterima oleh pemegang saham tidak berdampak pada peningkatan maupun penurunan nilai perusahaan. Berdasarkan hasil dari pengamatan, masih terdapat sebagian dari perusahaan yang tidak melakukan pembagian dividen kepada investor. Sedangkan bagi perusahaan yang melakukan pembagian dividen, investor pada dasarnya menganggap bahwa nilai pendapatan dividen yang diterima lebih rendah dibandingkan dengan nilai capital gain yang akan diterima di masa depan. Hal ini berkaitan dengan teori tax preference yang menyebutkan bahwa pajak atas pendapatan dividen lebih besar dibandingkan pajak atas capital gain. Investor akan lebih senang apabila laba bersih yang diterima perusahaan diinvestasikan ke dalam laba ditahan dengan harapan investor akan menerima capital gain yang lebih tinggi di masa depan dengan tingkat pajak yang rendah.

Penelitian ini berbeda dengan penelitian yang dilakukan oleh (Rizqia, Aisjah, \& Sumiati, 2013), (Faridah, 2016), (Ramadan, 2016) dan (Sofyaningsih \& Hardiningsih, 2011)

$\begin{array}{lcc}\begin{array}{l}\text { Pengaruh } \\ \text { terhadap }\end{array} & \begin{array}{c}\text { Keputusan } \\ \text { Nilai }\end{array} & \begin{array}{c}\text { Pendanaan } \\ \text { Perusahaan }\end{array} \\ \text { Manufaktur } & & \end{array}$


Hasil penelitian menemukan bahwa kebijakan pendanaan tidak berpengaruh signifikan terhadap nilai perusahaan. Hasil penelitian ini sejalan dengan penelitian yang dilakukan oleh (Faridah, 2016), (Meidiawati, 2016) dan (Rahayu \& Asandimitra, 2014). Besar kecilnya hutang perusahaan tidak memberikan pengaruh pada perubahan nilai perusahaan. Hal tersebut dikarenakan sebagian besar perusahaan manufaktur memiliki sumber dana internal yang cukup besar untuk membiayai aktivitas investasinya. Apabila perusahaan membutuhkan sumber dana eksternal, investor menganggap bahwa perusahaan masih memiliki kemampuan yang baik dalam membayar bunga dan pokok pinjaman pada saat jatuh tempo.

Hasil penelitian ini tidak sejalan dengan penelitian yang dilakukan oleh (Wijaya, 2016), (Sukirni, 2012), (Faridah, 2016), (Sofyaningsih \& Hardiningsih, 2011), (Rizqia, Aisjah, \& Sumiati, 2013).

\section{Pengaruh Kebijakan Profitabilitas terhadap Nilai Perusahaan Manufaktur}

Hasil penelitian menemukan bahwa kebijakan profitabilitas tidak berpengaruh signifikan terhadap nilai perusahaan. Hasil ini sejalan dengan penelitian yang dilakukan oleh (Meidiawati, 2016) dan (Rahayu \& Asandimitra, 2014). Peningkatan profitabilitas perusahaan tidak memberikan jaminan bagi peningkatan nilai perusahaan. Apabila profitabilitas perusahaan meningkat namun harga saham di pasar modal tetap berada pada titik dan harga yang sama maka tidak akan memengaruhi nilai perusahaan. Hal ini dapat disebabkan karena perusahaan bermain pada level harga saham yang aman atau harga saham perusahaan di pasar modal sudah mencapai titik optimal sehingga perusahaan tidak bisa lagi menaikkan harga saham dalam periode tertentu.

Hasil penelitian ini berbeda dengan penelitian yang dilakukan oleh (Sudiyatno, Puspitasari, \& Kartika, 2012), (Ernawati, 2015), (Welley \& Untu, 2015), (Meidiawati, 2016), (Sucuahi \& Cambarihan, 2016), (Rizqia, Aisjah, \& Sumiati, 2013), dan (Wijaya, 2016).

\section{Pengaruh Cash Holding terhadap Nilai Perusahaan Manufaktur}

Hasil penelitian menemukan bahwa cash holding tidak berpengaruh signifikan terhadap nilai perusahaan. Hasil penelitian ini sejalan dengan penelitian yang dilakukan oleh (Rahayu \& Asandimitra, 2014). Besarnya kepemilikan kas yang ada dalam suatu perusahaan tidak menjadi jaminan bahwa investor akan menanamkan dana ke perusahaan. Kepemilikan kas yang besar dapat menyebabkan manajemen mengambil keputusan keuangan yang tidak tepat dan merugikan bagi investor. Oleh karena itu, jumlah kas yang ada dalam suatu perusahaan harus disesuaikan dengan aktivitas investasi yang akan dilakukan oleh perusahaan agar dapat berjalan dengan baik dan tepat sasaran.

Hasil penelitian ini tidak sejalan dengan penelitian yang dilakukan oleh (Zahedi, Talebi, \& Aval, 2015) dan (Isshaq, 2009).

$\begin{array}{lll}\begin{array}{l}\text { Pengaruh } \\ \text { terhadap } \\ \text { Manufaktur }\end{array} & \begin{array}{c}\text { Keputusan } \\ \text { Nilai }\end{array} & \begin{array}{r}\text { Investasi } \\ \text { Perusahaan }\end{array} \\ \text { Hasil } & \text { penelitian } & \text { menemukan }\end{array}$
bahwa keputusan investasi berpengaruh negatif dan signifikan terhadap nilai perusahaan. Hasil penelitian ini berbeda dengan penelitian yang dilakukan oleh 
(Rizqia, Aisjah, \& Sumiati, 2013), (Rahayu \& Asandimitra, 2014) dan (Faridah, 2016). Nilai IOS pada sebagian besar perusahaan manufaktur masih menunjukkan persentase yang rendah bahkan ada yang menunjukkan nilai negatif. Keputusan investasi yang akan diambil oleh perusahaan belum mendatangkan manfaat yang diharapkan oleh investor sehingga pada akhirnya akan menurunkan nilai perusahaan. Investor menginginkan manfaat lebih sebagai hasil dari adanya aktivitas investasi.

\section{PENUTUP}

\section{Kesimpulan}

Semakin besar ukuran perusahaan maka investor menganggap bahwa perusahaan sudah mempunyai aliran kas yang stabil untuk membiayai aktivitas investasinya sehingga mampu mengurangi potensi pendanaan yang berasal dari sumber eksternal. Proporsi kepemilikan manajerial yang rendah menjadikan pihak manajemen tidak merasa menjadi bagian dari perusahaan. Hal ini akan berimbas pada pengambilan keputusan yang tidak memperhatikan kepentingan pemegang saham sehingga berpotensi memunculkan agency problem. Namun, masalah ini masih dapat diminimalisir dengan adanya pengawasan yang dilakukan oleh pihak institusi sehingga membuat manajemen perusahaan akan berhati-hati dalam pengambilan keputusan investasi.

\section{Saran}

Saran yang dapat diberikan dalam penelitian ini adalah industri manufaktur diharapkan dapat mempertimbangkan kembali besar kecilnya proporsi kepemilikan saham manajerial dan kepemilikan saham institusional. Hal ini dilakukan untuk meminimalisir terjadinya agency problem. Perusahaan yang sehat adalah perusahaan yang mampu menghasilkan kinerja yang baik dan selaras dengan kepentingan perusahaan serta pemegang saham. Bagi penelitian selanjutnya diharapkan dapat melakukan penelitian lanjutan dengan melibatkan faktor eksternal perusahaan (seperti inflasi, tingkat suku bunga dan nilai tukar) serta melakukan penelitian terhadap indeks perusahaan yang terdaftar di BEI (Seperti indeks Kompas 100) sehingga dapat memberikan gambaran mengenai kondisi perusahaan di seluruh sektor.

\section{DAFTAR PUSTAKA}

Asif, A., \& Aziz, B. (2016). Impact of Capital Structure on Firm Value Creation - Evidence from the Cement Sector of Pakistan. International Journal of Research in Finance and Marketing , 231245.

Brealey. (2008). Fundamentals of Corporate Finance Sixth Edition. New York: Mcgraw Hill.

Darwis, H. (2012). Manajemen Laba terhadap Nilai Perusahaan dengan Corporate Goverance sebagai Pemoderasi. Jurnal Keuangan dan Perbankan , 45-55.

Dhani, I. P., \& Utama, A. D. (2017). Pengaruh Pertumbuhan Perusahaan, Struktur Modal dan Profitabilitas terhadap Nilai Perusahaan. Jurnal Riset Akuntansi dan Bisnis Airlangga, 135-148. 
Ernawati, D. (2015). Pengaruh Profitabilitas, Leverage dan Ukuran Perusahaan terhadap Nilai Perusahaan. Jurnal Ilmu \& Riset Akuntansi, 1-17.

Faridah, N. (2016). Pengaruh Keputusan Investasi, Pendanaan, Kebijakan Dividen dan Tingkat Suku Bunga Terhadap Nilai Perusahaan. Jurnal Ilmu dan Riset Akuntansi , 1-15.

Ghalandari, K. (2013). The Moderating Effects of Growth Opportunities on the Relationship between Capital Structure and Dividend Policy and Ownership Structure with Firm Value in Iran: Case Study of Tehran Securities Exchange. Research Journal of Applied Sciences, Engineering and Technology, 1424-1431.

Gultom, R., Agustina, \& Wijaya, S. W. (2013). Analisis Faktor-Faktor yang Mempengaruhi Nilai Perusahaan pada Perusahaan Farmasi di Bursa Efek Indonesia. Jurnal Wira Ekonomi Mikroskil , 51-60.

Indriyani, E. (2017). Pengaruh Ukuran Perusahaan dan Profitabilitas terhadap Nilai Perusahaan. Jurnal Akuntabilitas : Jurnal Ilmu Akuntansi , 333-348.

Isshaq, Z. (2009). Corporate Governance, Ownership Structure, Cash Holding and Firm Value on the Ghana Stock Exchange. Journal of Risk Finance , 488-499.

IDX. (2018). www.idx.co.id diakses tanggal 28 Mei 2018
Kasmir. (2010). Pengantar Manajemen Keuangan, Edisi 1. Jakarta: Kencana Prenada Media Group.

Kemenripen. (2018). www.kemenripen.go.id diakses tanggal 28 mei 2018

Meidiawati, K. (2016). Pengaruh Size, Growth, Profitabilitas, Struktur Modal, Kebijakan Dividen terhadap Nilai Perusahaan. Jurnal Ilmu \& Riset Akuntansi, 1-16.

Nhan, D. T., \& Ha, P. (2016). Cash Holding, State Ownership and Firm Value : The Case Of Vietnam. International Journal of Economics and Financial Issues, 110-114.

Octaliana, \& Rahayuningsih, D. A. (2013). Analisis Kepemilikan Managerial Berbasis pada Teori Keagenan. Jurnal Bisnis dan Akuntansi , 65-72.

Putu. (2014). Factors Affeting Firms Value of Indonesia Public Manufacturing Firms. International Journal of Business and Management Invention , 3544.

Rahayu, F. D., \& Asandimitra, N. (2014). Pengaruh Ukuran Perusahaan, Leverage, Profitabilitas, Kebijakan Dividen dan Cash Holding terhadap Nilai Perusahaan pada Sektor Manufaktur. Jurnal Ilmu Manajemen, 548-561.

Ramadan, I. Z. (2015). Leverage and The Jordanian Firms' Value : Empirical Evidence. International Journal of Economics and Finance, 75-81. 
Rizqia, D. A., Aisjah, S., \& Sumiati. (2013). Effect of Managerial Ownership, Financial Leverage, Profitability, Firm Sixe and Investment Opportunity on Dividend Policy and Firm Value. Research Journal of Finance and Accounting , 120-130.

Sabrin. (2016). The Effect of Profitability on Firm Value in Manufacturing Companies at Indonesia Stock Exchanga. The International Journal of Engineering and Sciences , 81-89.

Sari, O. T. (2013). Pengaruh Keputusan Investasi, Keputusan Pendanaan dan Kebijakan Dividen terhadap Nilai Perusahaan. Management Analysis Journal , 1-7.

Sofyaningsih, S. (2011). Struktur Kepemilikan, Kebijakan Dividen, Kebijakan Hutang dan Nilai Perusahaan . Dinamika Keuanan dan Perbankan , 68-87.

Sucuahi, W., \& Cambarihan, J. M. (2016). Influence of Profitability to the Firm Value of Diversified Companies in the Philippines. Accounting and Finance Research , 149-153.

Sudiyatno, B., Puspitasari, E., \& Kartika, A. (2012). The Company's Policy, Firm Performance, and Firm Value : AN Empirical Research on Indonesia Stock Exchange. American International Journal of Contemporary Research, 30-40.

Sugiyono. (2012). Metode Penelitian Bisnis. Bandung: CV Alfabeta.
Sukirni, D. (2012). Kepemilikan Manajerial, Kepemilikan Institusional, Kebijakan Dividen dan Kebijakan Hutang : Analisis Terhadap Nilai Perusahaan. Accounting Analysis Journal , 112.

Sutrisno. (2016). Capital Structure Determinants and Their Impact on firm Value : Evidence from Indonesia. Economic World, 179186.

Wahyudi, U., \& Prasetyaning, P. H. (2006). Implikasi Struktur Kepemilikan Terhadap Nilai Perusahaan : Dengan Keputusan Keuangan Sebagai Variabel Intervening. Simposium Nasional Akuntansi 9 (pp. 1-25). Padang: K-AKPM 17.

Welley, M., \& Untu, V. (2015). FaktorFaktor yang Mempengaruhi Nilai Perusahaan di Sektor Pertanian pada Bursa Efek Indonesia Tahun 2011-2013 . EMBA , 972-983.

Wijaya, E. (2016). Pengaruh Struktur Kepemilikan, Kebijakan Dividen, Kebijakan Pendanaan dan Profitabilitas terhadap Nilai Perusahaan. Jurnal Procuratio (Jurnal Ilmiah Manajemen), 1-14.

Wijaya, P., \& N.K., P. (2014). Pengaruh Likuiditas dan Kepemilikan Institusional terhadap Nilai Perusahaan Dimoderasi oleh Kebijakan Dividen. Jurnal Manajemen Universitas Udayana , 3768-3780.

Zahedi, J., Talebi, E., \& Aval, S. L. (2015). Ownership Concentration, Cash Holding and Firm Value. International Journal of Management, Accounting and Economics , 902-912. 